\title{
Samenwerkingsverbanden in de eerstelijnszorg rondom probleempatiënten: eerste ervaringen met een nieuw keuzeco-assistentschap huisartsgeneeskunde
}

\author{
R.A.M.J. Damoiseaux, L.J.P. Slegers, G.E.H.M. Rutten.
}

\section{Samenvatting}

Inleiding: Zorgstructuren rondom chronische patiënten in de eerste lijn komen tot nu toe weinig aan bod in het medisch onderwijs. In Utrecht is een keuzeco-assistentschap huisartsgeneeskunde ontwikkeld waarin studenten inzicht krijgen in de complexiteit van de organisatie in de eerstelijnszorg. De eerste ervaringen zijn gunstig.

Beschrijving: De co-assistenten zochten zelf een huisarts waar ze het co-assistentschap (acht weken) konden lopen. De huisarts selecteerde vijf patiënten met een chronisch, complex zorgprobleem. De student interviewde de patiënten en verschillende betrokken zorginstanties en maakte voor elke patiënt een zorgplan. Het eindverslag moest uit vijf zorgplannen bestaan en werd besproken met de begeleider uit de afdeling huisartsgeneeskunde. Een voldoende beoordeling werd gegeven als het eindverslag voldeed aan de eisen en de student blijk gaf van inzicht in de zorgstructuren. Twee van de zes studenten die het co-assistentschap hebben doorlopen, ondervonden problemen bij het organiseren van contacten met patiënten en zorginstellingen. Alle studenten oordeelden positief over het keuzeco-assistentschap. Ze hadden meer inzicht gekregen in de complexe problematiek van chronische patiënten in de huisartsenpraktijk. De huisartsen oordeelden ook positief. Zij wilden wel meer begeleiding vanuit de afdeling.

Beschouwing: Het co-assistentschap zal sterker gestructureerd worden en vier weken gaan duren. Er komt een werkboek voor de begeleidende huisarts. Deze zal de patiënten selecteren en studenten helpen bij het leggen van contacten met zorginstanties. Het co-assistentschap zal ook geëvalueerd worden. Gezien de eerste positieve ervaringen lijkt het keuzeco-assistentschap een waardevolle manier om studenten kennis te laten maken met de complexiteit van zorg rondom chronische patiënten in de eerste lijn. (Damoiseaux RAMJ, Slegers LJP, Rutten GEHM. Samenwerkingsverbanden in de eerstelijnszorg rondom probleempatiënten: eerste ervaringen met een nieuw keuzeco-assistentschap huisartsgeneeskunde. Tijdschrift voor Medisch Onderwijs 2002;21(3): 131-135.)

\section{Inleiding}

Voor patiënten met chronische complexe problematiek is meestal een combinatie van verschillende zorgsoorten noodzakelijk. ${ }^{1}$ Binnen de eerste lijn wordt de huisarts vaak als aanspreekpunt gezien en er wordt verwacht dat hij/zij kennis heeft van de verschillende zorgsoorten. In de onderwijssituatie valt de zorg voor dit soort patiënten vaak buiten de boot omdat de student maar een klein deel van het zorgproces meemaakt. Dit is het gevolg van de complexiteit en chroniciteit van het probleem en de beperkte duur van een co-assistentschap. De student ziet vaak alleen de zich op dat moment manifesterende 'acute' problemen.

Om de student toch meer inzicht te geven in de complexiteit van de organisatie van de zorg binnen de eerste lijn heeft de afdeling huisartsgeneeskunde van het Universitair Medisch Centrum Utrecht 
(UMCU) in 1998 een nieuw keuze-coassistentschap ontwikkeld. Dit co-assistentschap is geïnspireerd op de probleemgerichte community bases multiagency course, beschreven door Lennox en Petersen. ${ }^{2}$ Tijdens dit Engelse programma maken derdejaars medische studenten van de universiteit van Leicester gedurende twee maanden kennis met medischmaatschappelijke problemen. Iedere student verheldert de hulpvraag van een patiënt door middel van een interview en een gesprek met de betrokken hulpverlenende instanties over de geboden hulp. Daarbij maken de studenten gebruik van aanwijzingen en achtergrondinformatie uit een werkboek. De cursus wordt afgesloten met een case-management-opdracht, casuspresentatie en een evaluatie door de begeleiders.

Als doel van het keuzeco-assistentschap van de afdeling huisartsgeneeskunde van het UMCU werd gesteld dat de student een beter inzicht moest krijgen in de rol van de huisarts bij chronische patiënten met complexe problematiek en kennis moest maken met de uitgebreidheid van de eerstelijnszorg.

In dit artikel wordt de opzet van dit nieuwe keuzeco-assistentschap beschreven en worden de eerste ervaringen besproken.

\section{Opzet van het keuzeco-assistentschap complexiteit van zorg}

Het keuzeco-assistentschap in het 'oude' curriculum in Utrecht duurt acht weken en het is het laatste co-assistentschap voor het artsexamen. In het nieuwe curriculum zijn meerdere keuzeco-assistentschappen van vier weken gepland. De hier beschreven ervaringen betreffen het keuzeco-assistentschap van acht weken.

Om een aantal praktische redenen werd de co-assistent gevraagd om zelf een huis- arts te zoeken. Huisartsen in en om Utrecht worden al veel gevraagd voor onderwijs- en onderzoekstaken en wij wilden hen daarom niet met dit nieuwe co-assistentschap belasten. Daar komt bij dat, als een huisarts meerdere malen mee zou doen aan het keuzeco-assistentschap, er een grote kans bestaat dat steeds dezelfde patiënten worden belast. Een huisarts die bereid was om een student te begeleiden, kreeg van de afdeling een korte beschrijving van het doel van het keuzeco-assistentschap en een reprint van het artikel van Lennox en Petersen. Vervolgens werd aan de huisarts gevraagd om vijf patiënten te selecteren met een complex zorgprobleem waarbij minstens twee andere instanties dan de huisarts betrokken waren.

Vervolgens moest de student middels een interview met de patiënt diens zorgprobleem in kaart brengen en er achter zien te komen hoe de patiënt vond dat het probleem aangepakt werd door de ingeschakelde instanties. Een volgende stap was om middels interviews met de betrokken instanties de visie van de hulpverleners in kaart te brengen. Er zijn voor het co-assistentschap geen duidelijke richtlijnen voor deze interviews verstrekt en het was aan de student om al of niet structuur hierin aan te brengen. Met de verzamelde informatie diende de student een zorgprogramma voor de patiënt op te stellen en tevens aan te geven welke lacunes of doublures de bestaande zorgsituatie bevatte. Dit zorgprogramma werd besproken met de huisarts.

Het eindverslag van het keuzeco-assistentschap moest bestaan uit vijf zorgplannen met commentaar van de huisarts en een afsluitende conclusie. Dit eindverslag werd besproken met de begeleider vanuit de afdeling huisartsgeneeskunde (de eerste auteur, RD). De begeleidende huisarts 
gaf een beoordeling over de inzet en attitude van de student. Het keuzecoassistentschap werd als voldoende gekwalificeerd als de student het eindverslag gemaakt had als boven beschreven en in het afsluitend gesprek blijk gaf van voldoende inzicht in de zorgstructuur binnen de eerste lijn.

\section{De eerste ervaringen.}

In het eerste jaar (1999) waarin dit keuzeco-assistentschap geïntroduceerd werd, hebben zes studenten dit co-assistentschap doorlopen. Alle studenten hadden zelf contact gezocht met de afdeling huisartsgeneeskunde met de vraag of ze een keuzeco-assistentschap huisartsgeneeskunde konden lopen. Niemand had moeite met het vinden van een huisarts die de begeleiding op zich wilde nemen. De meerderheid vond een huisarts in de plaats waar de ouders woonden. Het aantal besproken patiënten varieerde van drie tot negen per student. Het aantal instanties waarmee de studenten kennismaakten varieerde van drie tot zes. De meest genoemde instanties waren: het regionaal indicatieorgaan (RIO), de thuiszorg, fysiotherapeut, dagopvang, verzorgingshuis of verpleeghuis en de sociaal-psychiatrisch verpleegkundige van de RIAGG.

Eén student, een voormalig wijkverpleegkundige, liep het keuzeco-assistentschap in haar voormalige werkgebied en selecteerde zelf enkele, haar reeds bekende, patiënten. Zij heeft slechts drie instanties gesproken en in het eindverslag kwam eigenlijk alleen de thuiszorg aan bod, naast de rol van de huisarts. Voor deze student had het co-assistentschap niet het beoogde resultaat. Een andere student liep het keuzeco-assistentschap in de zomer. Wegens onderbezetting in de vakantiemaanden was het daardoor moeilijk om alle instanties te interviewen.
Hierdoor kreeg hij onvoldoende zicht op de samenwerking tussen de verschillende instanties rondom de gekozen patiënten. Echter, gezien het experimentele karakter van dit co-assistentschap en het feit dat beiden een goede inzet en attitude getoond hadden, is het co-assistentschap wel als voldoende beoordeeld.

De andere vier studenten voldeden wel aan de doelstelling. Zij gaven blijk van voldoende inzicht in de zorgstructuur binnen de eerste lijn. Daarnaast hadden zij een visie ontwikkeld over niet-organisatiegerelateerde aspecten van de begeleiding van chronische patiënten, bijvoorbeeld over de autonomie van de patiënt. Eén student had zelfs, tot grote tevredenheid van de begeleidende huisarts, een uitgebreide sociale kaart gemaakt, inclusief contactpersonen.

Het oordeel van de studenten was bij alle zes positief. Naast het in kaart brengen van de probleempatiënten hadden zij ook in de dagelijkse praktijk van de huisarts meegekeken. Door dieper op de organisatie van de zorg bij sommige patiënten in te gaan werd met name de zorgtaak van de huisarts verhelderd voor de studenten. Ook kregen zij zicht op tekortkomingen in de zorg en frustraties bij patiënten en hulpverleners.

De begeleidende huisartsen hadden nooit eerder co-assistenten begeleid. De tijd die ze in de begeleiding staken in deze acht weken varieerde van zestien tot 25 uur. Deze uren werden besteed aan het selecteren van patiënten, het introduceren van de student in de praktijk en het praktijkgebied, het bespreken van de verslagen en bespreken van andere activiteiten van de student in de dagelijkse praktijk. Hun voornaamste bezwaar was de summiere begeleiding vanuit de afdeling. Maar ook voor hen was het een positieve ervaring om het zorgprobleem van enkele patiënten in kaart te krijgen. 


\section{Beschouwing}

Gezien deze eerste positieve ervaringen lijkt het keuzeco-assistentschap een waardevolle manier om studenten inzicht te laten verwerven in de complexiteit van de zorg rondom een deel van de patiënten binnen de eerste lijn. Het ligt in de bedoeling van de afdeling huisartsgeneeskunde om dit co-assistentschap meer te gaan structureren zodat het in een periode van vier weken in het nieuwe curriculum aangeboden kan worden. Met name moet er een werkboek gemaakt worden met een duidelijke rolbeschrijving voor de begeleidende huisarts. Duidelijk is geworden dat de patiënten door de begeleidende huisarts geselecteerd moeten worden. Als de duur van het co-assistentschap van acht naar vier weken gaat, moet de begeleidende huisarts ook faciliteren in de contacten met de instanties. Deze zaken kwamen duidelijk aan het licht bij de student die zelf de patiënten geselecteerd had en bij de student die in de vakantieperiode met bijna geen enkele instantie in gesprek kwam. Voor deze beide studenten was het co-assistentschap niet compleet te noemen. Eveneens moet er een theoretisch kader van de zorgstructuren binnen de eerste lijn gegeven worden. Evenals in de Engelse situatie moet in het werkboek een beschrijving opgenomen worden hoe het interview afgenomen moet worden en op welke punten gelet moet worden. Dit laatste met als doel dat de student aandacht besteed aan de belangrijkste aspecten voor een goede zorg (fysieke toestand van de patiënt, psychische en sociale situatie, financiële situatie, maar ook de organisatorische aspecten van het in gang zetten van de zorg). Ook zullen de criteria vermeld moeten worden waaraan de student na afloop van het co-assistentschap moet voldoen. In het artikel van Lennox wordt hiervoor een goede lijst gegeven met tevens gradaties in de beoordeling.

Tot slot zal het ontwikkelde co-assistentschap geëvalueerd moeten worden middels enquêteformulieren voor de studenten, begeleidende huisartsen, instanties en betrokken patiënten, met name om een verdere verfijning van deze vorm van onderwijs te realiseren. 3 Samenvattend, menen wij dat het hier beschreven keuzeonderwijs een goede mogelijkheid biedt om een specifiek aspect van de huisartsgeneeskunde in het onderwijs aan te bieden voor geïnteresseerde studenten.

\section{Literatuur}

1. Ruiter ARM de, Bloemers JW. Zorgcoördinatie voor lastige patiënten. Medisch Contact 1999;54: 28-30.

2. Lennox A, Petersen S. Development and evaluation of a community based, multiagency course for medical students: descriptive survey. BMJ 1998;316:596-9.

3. Wilkes M, Bligh J. Evaluating educational interventions. BMJ 1999;318:1269-72.

De auteurs:

Dr. R.A.M.J. Damoiseaux, huisarts, destijds coördinator keuzeco-schappen, Julius Centrum voor Huisartsgeneeskunde en Patiëntgebonden Onderzoek, Afdeling Huisartsgeneeskunde, UMC Utrecht.

Mw. L.J.P. Slegers, arts, destijds co-assistent.

Prof. dr. G.E.H.M. Rutten, huisarts, Julius Centrum voor Huisartsgeneeskunde en Patiëntgebonden Onderzoek, Afdeling Huisartsgeneeskunde UMC, Utrecht.

Correspondentieadres:

Dr. R.A.M.J. Damoiseaux, Flessenbergerweg 5, 8191 LH Wapenveld, Tel: 038-4477495, r.damoiseaux@tiscali.nl. 


\section{Summary}

Introduction: Up to now the organisation of primary care for patients suffering from a chronic illness has only infrequently been addressed in undergraduate medical education. At Utrecht Medical School an elective clerkship was developed which focusses on encounters with chronically ill patients and community care services involved in their care.

Description: Six students participated in the clerkship. They had to find a GP who was willing to supervise the eight week clerkship. The GP selected five patients with a chronic, complicated condition. The student interviewed the patients and several services involved in their care, and wrote a care plan for each patient. The student's final clerkship report contained five care plans and was discussed with the supervisor from the department of primary care. Students passed the clerkship when the report was approved and they could demonstrate adequate insight into the health care system. Two students had difficulty in contacting a sufficient number of patients and care services. Both students and GPs regarded the clerkship as a positive experience, albeit that the GPs desired more coaching from the department.

Discussion: The clerkship will be reduced to four weeks and its structure improved. GP instructions will be developed. The GP will select patients and facilitate contacts with care services. Extensive evaluation of the clerkship is planned. The positive first results suggest that the elective clerkship is a good way of offering students insight into the complex structure of primary care for the chronically ill. C. Damoiseaux RAMJ, Slegers LJP, Rutten GEHM. Primary care for patients suffering from a complicated chronic illness: the first experiences with an elective clerkship in primary care. Dutch Journal of Medical Education 2002;21(3): 131-135.) 